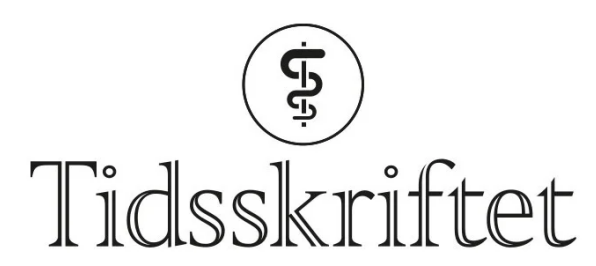

DEN NORSKE LEGEFORENING

\title{
Kun brystkompresjon ved hjertestans
}

\author{
NYHETER
}

\section{ELINE FEIRING}

Email: eline.feiring@legeforeningen.no Tidsskriftet

\section{Brystkompresjoner alene kan være godt nok ved hjertestans. Dette viser to nye randomiserte studier.}

I en svensk prospektiv randomisert studie ble 1276 pasienter med mistanke om hjertestans inkludert (1). Pasientene ble behandlet av privatpersoner som hadde ringt nødtelefonen og der fått veiledning av spesialutdannet helsepersonell. Pasientene ble randomisert til å motta enten standard hjerte-lunge-redning eller kun hjertekompresjoner.

Overlevelsen etter 30 dager var like god i begge grupper; 8,7 \% i gruppen som kun fikk hjertekompresjoner og 7,0 \% i gruppen som fikk standard hjerte-lunge-redning. En

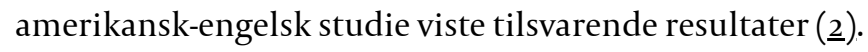

- Disse studiene bekrefter resultater fra ikke-randomiserte studier, blant annet fra Norge, sier professor Petter Andreas Steen ved Oslo universitetssykehus. Ved kardial årsak til hjertestans betyr kanskje ikke munn-til-munn så mye, i hvert fall ikke ved telefoninstruksjon i hjerte-lunge-redning.

- Disse studiene innebærer imidlertid ikke at vi kan glemme opplæring i munn-til-munnmetoden, sier Steen. Resultatene kan delvis skyldes at det er vanskelig å instruere i munntil-munn-metoden via telefon. Viktigere er det at hjertestans hos de fleste barn og hos ca. en tredel av voksne ikke har kardiale årsaker, men skyldes manglende ventilasjon. I slike tilfeller er resultatet mye dårligere uten munn-til-munn. Det er også viktig at i land utenom Europa og Nord-Amerika har de fleste hjertestans ikke-kardiale årsaker, slik som drukning, ulykker eller fødselsasfyksi.

I Norge instruerer nok de fleste AMK-sentraler nå bare i hjertekompresjoner ved hjertestans med sannsynlig kardial årsak hos voksne pasienter, mens opplæring i hjertelunge-redning også omfatter munn-til-munn, sier Steen.

\section{LITTERATUR}

1. Svensson L, Bohm K, Castrén M et al. Compression-only CPR or standard CPR in out-of-hospital cardiac arrest. N Engl J Med 2010;363: 434-42. 
2. Rea TD, Fahrenbruch C, Culley L et al. CPR with chest compression alone or with rescue breathing. N Engl J Med 2010;363: 423-33.

Publisert: 7. oktober 2010. Tidsskr Nor Legeforen. DOI: 10.4045/tidsskr.10.0951

(C) Tidsskrift for Den norske legeforening 2023. Lastet ned fra tidsskriftet.no 26. april 2023. 